\title{
TWO NEW CARBAPENEM ANTIBIOTIC-PRODUCING ACTINOMYCETES: KITASATOSPORIA PAPULOSA SP. NOV. AND KITASATOSPORIA GRISEA SP. NOV.
}

\author{
Yoshihiro Nakamura, EiJI Ono, Toru Kohda and Hiroshiro Shibai \\ Applied Research Department, Central Research Laboratories, Ajinomoto Co., Inc., \\ 1-1 Suzuki-cho, Kawasaki-ku, Kawasaki 210, Japan
}

(Received for publication May 18, 1988)

\begin{abstract}
Two new carbapenem antibiotic-producing actinomycetes, the cell-walls of which contain LL-diaminopimelic acid and meso-diaminopimelic acid, were isolated from soil. The two strains were subjected to taxonomic studies, which involved morphological, cultural, physiological and chemotaxonomical characterization, the latter including the cell-wall chemotype, whole-cell sugar composition, phospholipid composition, menaquinone system and DNA base composition. These strains were identified as new species of the genus Kitasatosporia. The proposed names are Kitasatosporia papulosa for strain AB-110 (IAM 13637, FERM 9000, JCM 7250) and Kitasatosporia grisea for strain AA-107 (IAM 13638, JCM 7249).
\end{abstract}

The carbapenem antibiotics exhibit potent and broad antibacterial activity, and potent $\beta$-lactamase inhibitory activity. They are powerful examples of naturally-occurring $\beta$-lactam antibiotics, such as penam (penicillins), cephem (cephalosporins), 7-methoxycephem (cephamycins), 7-formylaminocephem (cephabacin Fs), monocyclic $\beta$-lactam (nocardicins, sulfazecins and SQ-26180), clavam (clavulanic acids) and carbapenem (thienamycins, etc.) antibiotics.

Many carbapenem antibiotic-producing microorganisms have been isolated. However, they are limited to strains of the genera Streptomyces ${ }^{1 \sim 9)}$, Erwinia $^{10)}$ and Serratia ${ }^{10)}$. No microorganism in any other genus has been reported to be a carbapenem antibiotic producer. Therefore, we tried to isolate carbapenem antibiotic producers from among so-called 'rare actinomycetes', which are actinomycetes other than those of the genus Streptomyces.

We performed cell-wall analysis to select 'rare actinomycetes'. Cell-wall components, such as LL-diaminopimelic acid $\left(\mathrm{A}_{2} \mathrm{pm}\right)$, meso- $\mathrm{A}_{2} \mathrm{pm}$, glycine, arabinose, galactose, xylose and madurose, have been used as key criteria in the classification of actinomycetes ${ }^{11,12)}$. Among such cell-wall components, the isomer types of $\mathrm{A}_{2} \mathrm{pm}$ can be used for the differentiation of 'rare actinomycetes' from the genus Streptomyces. The latter together with some other genera (Streptoverticillium, Microellobosporia, Sporichthya, Nocardioides and Erytrosporangium) contain only LL-A 2 pm. However, most other actinomycete-genera contain only meso- $\mathrm{A}_{2} \mathrm{pm}$, both LL- and meso- $\mathrm{A}_{2} \mathrm{pm}$, or no $\mathrm{A}_{2} \mathrm{pm}$. Therefore, determination of the isomer type of $A_{2} \mathrm{pm}$ is practically useful for the selection of 'rare actinomycetes'.

A search for carbapenem antibiotic-producing 'rare actinomycetes' by our screening program led to the isolation of two new producers, AB-110 and AA-107. The cell-walls of most of the five hundreds or more of carbapenem antibiotic producers found in our screening contained only LL- $A_{2}$ pm. Therefore, they were considered to belong to the genus Streptomyces and thus were not studied further. However, the cell-walls of strains $\mathrm{AB}-110$ and AA-107 contained both LL- and meso- $\mathrm{A}_{2} \mathrm{pm}$. This type of carbapenem antibiotic-producing actinomycetes has never been reported previously. Strain AB-110 was found to produce a carbapenem antibiotic, AB-110-D ${ }^{13)}$, which showed not only potent 
and broad antibacterial activity but also potent $\beta$-lactamase inhibitory activity. This antibiotic has never been reported as an actinomycete-product.

Several strains of actinomycetes which contain both the LL- and meso-isomers of $\mathrm{A}_{2} \mathrm{pm}$ have been reported. КАWАMOTо et al. ${ }^{14)}$ found that some strains in the genus Micromonospora contain a small amount of $\mathrm{LL}-\mathrm{A}_{2} \mathrm{pm}$ together with a large amount of meso- $\mathrm{A}_{2} \mathrm{pm}$. A same finding was also reported by NeLson et al. ${ }^{15}$. OOMURA et al. ${ }^{16 \sim 21)}$ isolated some strains which have the Streptomyces morphology but contain both LI- and meso- $\mathrm{A}_{2} \mathrm{pm}$ in equal amounts. OMURA et al. ${ }^{\text {(t) }}$ proposed a new genus Kitasatosporia for their isolates. The genus Kitasatosporia is characterized by the morphological resemblance to the genus Streptomyces and the cell-wall chemotype $\mathrm{X}^{17)}$ (both LL- and meso- $\mathrm{A}_{2} \mathrm{pm}$, glycine and galactose). Recently, TAmamura et al. ${ }^{22)}$, SHMMazu et $a l .{ }^{23)}$, INAOKa et al. ${ }^{24)}$ and Iwam et al. ${ }^{25)}$ also reported some strains belonging to the genus Kitasatosporia. TAKAHASHI et al. ${ }^{26)}$ reported a strain belonging to the genus Nocardiopsis, which contains a small amount of $L \mathrm{~L}-\mathrm{A}_{2} \mathrm{pm}$ together with a large amount of meso- $\mathrm{A}_{2} \mathrm{pm}$.

In this paper we describe two new species, Kitasatosporia papulosa sp. nov. AB-110 and Kitasatosporia grisea sp. nov. AA-107, and compare them with those strains containing both LL- and meso$\mathrm{A}_{2} \mathrm{pm}$.

\section{Materials and Methods}

Isolation and Selection of Microorganisms from Soil

Strains AB-110 and AA-107 were isolated through heat treatment of soil samples ${ }^{27}$, the standard dilution and plating technique, and selective isolation for carbapenem antibiotic-producing actinomycetes ${ }^{28)}$. The $\mathrm{A}_{2} \mathrm{pm}$ type was determined by the method of HASEGAWA et al. ${ }^{28)}$, immediately after they were identified as carbapenem antibiotic producers ${ }^{28)}$. One colony grown on oatmeal - yeast extract - malt extract (OMYM) agar was hydrolyzed with $0.1 \mathrm{ml}$ of $6 \mathrm{~N} \mathrm{HCl}$ at $120^{\circ} \mathrm{C}$ for 15 minutes and then subjected to ascending chromatography on a thin cellulose sheet with a solvent system of methanol $-6 \mathrm{~N} \mathrm{HCl}$ - pyridine - water $(80: 26: 4: 10)$ for 3 hours. Isomers of $\mathrm{A}_{2}$ pm were detected by means of the ninhydrin reaction. OMYM medium contained of oatmeal $20 \mathrm{~g}$, malt extract $2 \mathrm{~g}$, yeast extract $2 \mathrm{~g}$, glucose $2 \mathrm{~g}, \mathrm{CoSO}_{4} \cdot 7 \mathrm{H}_{2} \mathrm{O} 0.006 \mathrm{~g}, \mathrm{ZnSO}_{4} \cdot 7 \mathrm{H}_{2} \mathrm{O} 0.003 \mathrm{~g}, \mathrm{MnSO}_{4} \cdot 4 \sim 5 \mathrm{H}_{2} \mathrm{O} 0.003 \mathrm{~g}$ and $\mathrm{FeSO}_{4} \cdot 7 \mathrm{H}_{2} \mathrm{O} 0.003 \mathrm{~g}$ per 1 liter of distilled water, and was adjusted to $\mathrm{pH}$ 7.0.

Strain AB-110 was isolated from a soil sample collected at Mitsuike Park in Yokohama-city, Japan. The air-dried soil was heated at $100^{\circ} \mathrm{C}$ for 1 hour and then ground into a powder ${ }^{27}$. One $\mathrm{ml}$ of a 1,000-fold diluted soil suspension was plated on OMYM medium containing Augmentin (200 $\mu \mathrm{g} / \mathrm{ml})$. Strain AA-107 was isolated from a soil sample collected at Tosyogu-shrine in Nikko-city, Japan. The air-dried soil was heated at $120^{\circ} \mathrm{C}$ for 1 hour and then ground into a powder. One $\mathrm{ml}$ of a 1,000-fold diluted soil suspension was plated on AV medium ${ }^{27)}$ containing Augmentin $(200 \mu \mathrm{g} / \mathrm{ml})$. Both strains were isolated after incubation of the plate at $28^{\circ} \mathrm{C}$ for 3 weeks. Among about five hundred carbapenem antibiotic producers found in our laboratories, strains AB-110 and AA-107 were unique in having not only $\mathrm{LL}_{\mathrm{L}} \mathrm{A}_{2} \mathrm{pm}$ but also meso- $\mathrm{A}_{2} \mathrm{pm}$ in their cell-walls. Stock cultures for the strains studied were grown on an $\mathrm{OMYM}$ agar slant and preserved at $-85^{\circ} \mathrm{C}$.

\section{Identification Methods}

\section{Microorganisms Studied}

Strains AB-110 and AA-107 were studied taxonomically together with authentic strains, Kitasatosporia setalba IFO 14216 (=ATCC 33774, Type strain) ${ }^{17)}$ (Kitasatosporia seta ${ }^{18}{ }^{8}$ ), Kitasatosporia griseola IFO 14371 (Type strain) ${ }^{21)}$ and Kitasatosporia phosalacinea IFO 14372 (Type strain) ${ }^{21)}$, for comparison.

Each microorganism was cultivated in a 500-ml Sakaguchi flask containing $100 \mathrm{ml}$ of SS medium on a reciprocal shaker at $28^{\circ} \mathrm{C}$ for 3 days. Then the cells were centrifuged and washed three times 
with sterile saline. The washed cells were used as the inoculum for various studies. SS medium contained of starch $20 \mathrm{~g}$, glucose $5 \mathrm{~g}$, Soytone (Difco Lab., Michigan, U.S.A. ${ }^{\dagger}$ ) $12 \mathrm{~g}$, yeast extract $5 \mathrm{~g}$, $\mathrm{KH}_{2} \mathrm{PO}_{4} 1 \mathrm{~g}, \mathrm{CoSO}_{4} \cdot 7 \mathrm{H}_{2} \mathrm{O} 0.006 \mathrm{~g}, \mathrm{ZnSO}_{4} \cdot 7 \mathrm{H}_{2} \mathrm{O} 0.003 \mathrm{~g}, \mathrm{MnSO}_{4} \cdot 4 \sim 5 \mathrm{H}_{2} \mathrm{O} 0.003 \mathrm{~g}$ and $\mathrm{FeSO}_{4} \cdot$ $7 \mathrm{H}_{2} \mathrm{O} 0.003 \mathrm{~g}$ per 1 liter of distilled water, and was adjusted to $\mathrm{pH} 7.0$.

\section{Morphological Characteristics}

Morphological characteristics were examined for cultures grown at $28^{\circ} \mathrm{C}$ for $2 \sim 4$ weeks on oatmeal agar (International Streptomyces Project (ISP) medium 3) and inorganic salts - starch agar (ISP medium 4). Examination was made with a photomicroscope (Optiphoto model with an ELWD lens; Nikon Co., Ltd., Japan.)

The spore surface was investigated under a scanning electron microscope (SEM; JSM-T20 type; Japan Electron Optics Laboratory Co., Ltd., Japan). The specimen for the SEM was prepared as follows. An agar block on which a microorganism grew was fixed with formalin gas, dehydrated through graded ethanol series, transferred into isoamyl acetate, dried by a critical point dryer (HCP-1 type; Hitachi Seisakusho Co., Ltd., Japan) and finally coated with gold by an ion coater (SC-701 type; Sanyu Densi Co., Ltd., Japan).

\section{Cultural and Physiological Characteristics}

Cultural and physiological characteristics were examined by the methods reported by SHIRLing and GOTTLIEB ${ }^{30)}$, and WAKSMAN ${ }^{31}$ as follows.

The media used were Tryptone - yeast extract broth (ISP medium 1$)^{30)}$, yeast extract - malt extract agar (ISP medium 2) ${ }^{30)}$, oatmeal agar (ISP medium 3) ${ }^{30)}$, inorganic salts - starch agar (ISP medium $4)^{30)}$, glycerol - asparagine agar (ISP medium 5$)^{302}$, peptone - yeast extract - iron agar (ISP medium 6) ${ }^{30)}$, tyrosine agar (ISP medium 7) ${ }^{303}$, nitrate broth (ISP medium 8) ${ }^{30)}$ and Pridham and Gottlieb medium (ISP medium 9) ${ }^{30)}$ (Difco Lab. ${ }^{\dagger}$ ). Sucrose - nitrate agar ${ }^{31}$ ), glucose - asparagine agar ${ }^{31}$, nutrient agar, gelatin agar ${ }^{312}$ and litmus milk ${ }^{311}$ were also used. Growth ranges as to temperature and $\mathrm{pH}$, and the tolerance range as to $\mathrm{NaCl}$ were determined in yeast extract - malt extract agar (ISP medium 2). The utilization of carbon sources was examined by growth on Pridham and Gottlieb medium (ISP medium 9) containing $1 \%$ of each carbon source.

Each medium was seeded with washed cells as mentioned above, followed by incubation at $28^{\circ} \mathrm{C}$ for $2 \sim 4$ weeks.

Colors were determined by comparison with the color plates in the 'Methuen Handbook of Colour ${ }^{322}$.

Chemical Analyses of Whole-Cells and a Cell-wall Preparation

A microorganism was cultivated in a 500-ml Sakaguchi flask containing $100 \mathrm{ml}$ of SS medium on a reciprocal shaker at $28^{\circ} \mathrm{C}$ for 3 days. The cells were collected by centrifugation, washed with sterile saline and then used as whole-cells. Cell-walls were prepared according to the method of YAMAGUCHI $^{333}$. Amino acids and sugars in whole-cells and the cell-wall preparation were determined as described by BECKER et al. ${ }^{34)}$ The relative quantities of LL- and meso- $\mathrm{A}_{2} \mathrm{pm}$ were determined with a TLC scanner (CS-910 model; Shimazu Seisakusho Co., Ltd., Japan) at $410 \mathrm{~nm}$.

The following four kinds of cells were prepared for analyses of $\mathrm{A}_{2} \mathrm{pm}$ according to the method of TAKAHASH et al..$^{20)}$; submerged spores and filamentous mycelia in a liquid-culture of SS medium, and aerial spores and substrate mycelia in an agar-culture of inorganic salts - starch agar medium (grown at $28^{\circ} \mathrm{C}$ for 2 weeks.)

Analyses of the Phospholipid and Quinone Compositions

Cells, cultivated with shaking in SS medium, were collected by centrifugation, washed with sterile saline and then freeze-dried. Lipids were extracted from the freeze-dried cells with a chloroform methanol $(2: 1)$ mixture. Phospholipids were purified and identified by the method of LECHEVALIER et $a l .{ }^{35)}$. Quinones were purified and identified by the method reported by TAMAOKA et al. ${ }^{36)}$.

† Difco Manual 10th Ed., Difco Laboratories, Michigan, U.S.A., 1983. 


\section{Analysis of the DNA Base Composition}

A microorganism was cultivated in a $500-\mathrm{ml}$ Sakaguchi flask containing $100 \mathrm{ml}$ of SS medium supplemented with $0.5 \%$ of glycine $e^{37)}$ on a reciprocal shaker at $28^{\circ} \mathrm{C}$ for 3 days, and then the cells were collected by centrifugation. DNA was extracted from the cells and purified by the phenol method of SAITo and MiUra ${ }^{38)}$. The guanine plus cytosine content $(\mathrm{G}+\mathrm{C}$ content) of DNA was determined by the method of TAMAOKA and KomaGaTA ${ }^{39}$. DNA from Escherichia coli $\mathrm{K}-12$ was used as a reference. Its $\mathrm{G}+\mathrm{C}$ content was presumed to be $51.4 \%$.

\section{Susceptibility to Antibiotics}

The susceptibility of strains AB-110 and AA-107 to antibiotics was examined by placing susceptibility discs (Showa discs; Showa Yakuhin Kako Co., Ltd., Japan) on the agar surface of assay plates. The assay plates consisted of $30 \mathrm{ml}$ of yeast extract - malt extract agar (ISP medium 2) and $1 \mathrm{ml}$ of each seed culture in a plastic petri dish $(75 \times 225 \mathrm{~mm}$; Eiken Kagaku Ltd., Japan). The susceptibility discs were impregnated with benzylpenicillin $(20 \mathrm{U})$, cephalothin $(30 \mu \mathrm{g})$, streptomycin $(50 \mu \mathrm{g})$, tetracycline $(200 \mu \mathrm{g})$, erythromycin $(50 \mu \mathrm{g})$, fosfomycin $(200 \mu \mathrm{g})$ or chloramphenicol $(100 \mu \mathrm{g})$. After incubation for 2 days at $28^{\circ} \mathrm{C}$, the diameters of the inhibition zones were determined.

\section{Results and Discussion}

\section{Morphological Characteristics}

Strains AB-110 and AA-107 showed almost the same morphological characteristics, except for the spore surface. Long aerial mycelia developed from substrate mycelia. The structure of the aerial mycelia was of the Rectus-Flexibilis type. The mature spore chains comprised more than 20 spores each. The spores were cylindrical and $0.7 \sim 0.9 \times 0.8 \sim 1.4 \mu \mathrm{m}$ in size. The substrate mycelia in agar media were not fragmented. No zoospores, sporangia, sclerotia or any other special structures were formed. The spore surface of strain AA-107 was smooth, however, that of strain AB-110 was smooth with some warts, as shown in Fig. 1.

\section{Cultural and Physiological Characteristics}

Strain AB-110 grew abundantly on yeast extract - malt extract agar (ISP medium 2), oatmeal agar (ISP medium 3), inorganic salts - starch agar (ISP medium 4), peptone - yeast extract - iron agar (ISP medium 6), tyrosine agar (ISP medium 7) and nutrient agar. The color of the aerial mycelia that grew on oatmeal agar (ISP medium 3), inorganic salts - starch agar (ISP medium 4) and glycerol -

Fig. 1. Scanning electron micrographs of aerial spores of strains AB-110 (A) and AA-107 (B).

(A)

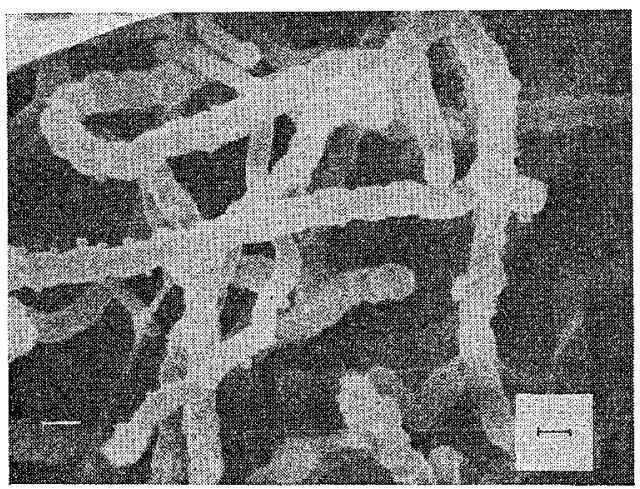

(B)

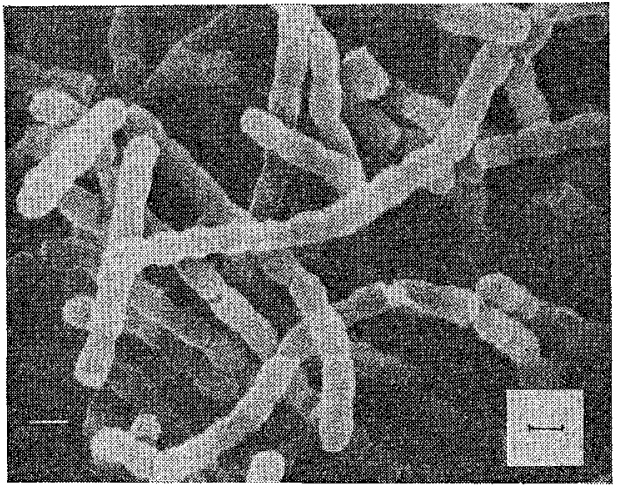

Cultured on inorganic salts - starch agar media for 3 weeks at $28^{\circ} \mathrm{C}$.

Bars represent $1 \mu \mathrm{m}$. 
Table 1. Cultural characteristics of strains AB-110 and AA-107.

\begin{tabular}{|c|c|c|c|c|}
\hline Medium & & $\mathrm{AB}-110$ & & AA-107 \\
\hline \multirow{4}{*}{$\begin{array}{l}\text { Yeast extract - malt extract agar } \\
\text { (ISP medium 2) }\end{array}$} & G: & Abundant & G: & Abundant \\
\hline & AM: & Gray & AM: & Yellowish gray \\
\hline & SM: & Light brown & SM: & Olive brown \\
\hline & SP: & None & SP: & None \\
\hline \multirow{4}{*}{$\begin{array}{l}\text { Oatmeal agar } \\
\text { (ISP medium 3) }\end{array}$} & $\mathrm{G}:$ & Abundant & G: & Abundant \\
\hline & AM: & Light gray & AM: & Yellowish gray \\
\hline & SM: & Grayish yellow & SM: & Olive brown \\
\hline & SP: & None & SP: & None \\
\hline \multirow{4}{*}{$\begin{array}{l}\text { Inorganic salts - starch agar } \\
\text { (ISP medium 4) }\end{array}$} & G: & Abundant & G: & Abundant \\
\hline & AM: & Gray & AM: & Yellowish gray \\
\hline & SM: & Light brown & SM: & Grayish green \\
\hline & SP: & None & SP: & None \\
\hline \multirow{4}{*}{$\begin{array}{l}\text { Glycerol - asparagine agar } \\
\text { (ISP medium 5) }\end{array}$} & $\mathrm{G}:$ & Moderate & $\mathrm{G}$ : & Poor \\
\hline & AM: & Light gray & AM: & Light gray \\
\hline & SM: & Grayish yellow & SM: & Grayish green \\
\hline & SP: & None & SP: & None \\
\hline \multirow{4}{*}{$\begin{array}{l}\text { Peptone - yeast extract - iron agar } \\
\text { (ISP medium 6) }\end{array}$} & $\mathrm{G}:$ & Abundant & $\mathrm{G}$ : & Abundant \\
\hline & AM: & Gray & AM: & Yellowish gray \\
\hline & SM: & Light brown & SM: & Grayish green \\
\hline & SP: & None & SP: & None \\
\hline \multirow{4}{*}{$\begin{array}{l}\text { Tyrosine agar } \\
\text { (ISP medium 7) }\end{array}$} & $\mathrm{G}:$ & Abundant & $\mathrm{G}:$ & Moderate \\
\hline & AM: & Light gray & AM: & Grayish yellow \\
\hline & SM: & Grayish yellow & SM: & Olive \\
\hline & SP: & None & SP: & None \\
\hline \multirow[t]{4}{*}{ Sucrose - nitrate agar } & $\mathrm{G}:$ & Moderate & $\mathrm{G}:$ & Poor \\
\hline & AM: & White & AM: & White \\
\hline & SM: & Pearl & SM: & White yellow \\
\hline & SP: & None & SP: & None \\
\hline \multirow[t]{4}{*}{ Glucose - asparagine agar } & $\mathrm{G}:$ & Moderate & G: & Poor \\
\hline & AM: & Light gray & AM: & Grayish yellow \\
\hline & SM: & Grayish yellow & SM: & Olive \\
\hline & SP: & None & SP: & None \\
\hline \multirow[t]{4}{*}{ Nutrient agar } & $\mathrm{G}:$ & Abundant & $G:$ & Abundant \\
\hline & AM: & None & AM: & None \\
\hline & SM: & Dark pearl & SM: & Olive \\
\hline & SP: & None & SP: & None \\
\hline
\end{tabular}

G, growth; AM, aerial mycelium; SM, substrate mycelium; SP, soluble pigment.

asparagine agar (ISP medium 5) was light gray to gray. The substrate mycelia were light brown or grayish yellow. A soluble pigment was not formed (Table 1).

Strain AB-110 grew at 14 to $36^{\circ} \mathrm{C}$, at pH 5.0 to 9.5 , and in medium containing less than $3.5 \%$ of $\mathrm{NaCl}$. Starch was hydrolyzed. Gelatin was liquefied. Milk was peptonized but not coagulated. Nitrate was not reduced. Melanin was not produced. Good growth occurred on D-xylose and $\mathrm{D}$-glucose as single carbon sources, moderate growth on L-arabinose, D-fructose, sucrose, $i$-inositol, L-rhamnose, raffinose and D-mannitol, and no growth on cellulose.

Strain AA-107 grew abundantly on yeast extract - malt extract agar (ISP medium 2), oatmeal agar (ISP medium 3), inorganic salts - starch agar (ISP medium 4), peptone - yeast extract - iron agar (ISP medium 6) and nutrient agar. The color of the aerial mycelia that grew on oatmeal agar (ISP medium 3), inorganic salts - starch agar (ISP medium 4) and glycerol - aspargine agar (ISP medium 5) was yellowish gray or light gray. The substrate mycelia were olive brown to grayish green. A 
soluble pigment was not formed (Table 1).

Strain AA-107 grew at 15 to $38^{\circ} \mathrm{C}$, at $\mathrm{pH} 5.0$ to 9.5 , and in medium containing less than $4.5 \%$ of $\mathrm{NaCl}$. Starch was hydrolyzed. Gelatin was liquefied. Milk was peptonized but not coagulated. Nitrate was not reduced. Melanin was not produced. Good growth occurred on Dxylose and D-glucose as carbon sources, moderate growth on D-fructose, L-rhamnose and D-mannitol, poor growth on L-arabinose, and no growth on sucrose, $i$-inositol, raffinose or cellulose.

\section{Chemotaxonomical Characteristics}

The cell-walls of strains AB-110 and AA-107 in submerged-cultures contained LL- and meso$\mathrm{A}_{2} \mathrm{pm}$, glycine and galactose, therefore, they were considered to have cell-wall chemotype $\mathrm{X}^{17)}$. Wholecells contained galactose. The ratio of LL- and meso- $\mathrm{A}_{2} \mathrm{pm}$ in submerged mycelia was roughly estimated to be $3: 1$. Only LL-A $\mathrm{A}_{2} \mathrm{pm}$ was detected in submerged spores and aerial spores. However, both isomers seemed to be present in filamentous and substrate mycelia. This may be due to the difficulties in separating spores from mycelia. The phospholipid detected was phosphatidylethanolamine. Hence the phospholipid pattern was of type $\mathrm{II}^{352}$. Menaquinones were detected but not ubiquinone. The major menaquinones were MK-9 $\left(\mathrm{H}_{8}\right)$ and $\mathrm{MK}-9\left(\mathrm{H}_{8}\right)$, as shown in Table 2. The $\mathrm{G}+\mathrm{C}$ contents of strains $\mathrm{AB}-110$ and $\mathrm{AA}-107$ were $72.0 \pm 0.5 \%$ and $72.0 \pm 0.3 \%$, respectively.

\section{Susceptibility to Antibiotics}

Strains AB-110 and AA-107 were resistant to benzylpenicillin (20 U) and cephalothin $(30 \mu \mathrm{g})$. However, they were sensitive to streptomycin $(50 \mu \mathrm{g})$, tetracycline $(200 \mu \mathrm{g})$, erythromycin $(50 \mu \mathrm{g})$, fosfomycin $(200 \mu \mathrm{g})$ and chloramphenicol $(100 \mu \mathrm{g})$; streptomycin $(50 \mu \mathrm{g})$ produced $49 \mathrm{~mm}$ and $45 \mathrm{~mm}$ growth inhibition zones for strains AB-110 and AA-107, respectively; tetracycline (200 $\mu \mathrm{g})$ produced $32 \mathrm{~mm}$ and $35 \mathrm{~mm}$ zones; erythromycin $(50 \mu \mathrm{g})$ produced $23 \mathrm{~mm}$ and $30 \mathrm{~mm}$ zones; fosfomycin (200 $\mu \mathrm{g})$ produced $20 \mathrm{~mm}$ and $25 \mathrm{~mm}$ zones; and chloramphenicol $(100 \mu \mathrm{g})$ produced $34 \mathrm{~mm}$ and $30 \mathrm{~mm}$ zones.

\section{Identification of Strains AB-110 and AA-107}

The morphological characteristics of strains AB-110 and AA-107 resembled those of the genus Streptomyces. Long aerial mycelia developed from substrate mycelia. The mature spore chains comprised more than 20 spores each. The substrate mycelia were not fragmented. Sporangia, zoospores and sclerotia were not formed. Some chemotaxonomical characteristics also resembled those of the genus Streptomyces. The phospholipid (type II) and major menaquinones $\left(\mathrm{MK}-9\left(\mathrm{H}_{8}\right)\right.$ and MK-9 $\left(\mathrm{H}_{8}\right)$ ) were the same as those of the genus Streptomyces ${ }^{40 \sim 42)}$. The $\mathrm{G}+\mathrm{C}$ contents were $72 \%$. Those of Streptomyces species are generally distributed between 69 and $76 \%{ }^{42)}$. However, cell-wall and whole-cell compositions were not the same as those of the genus Streptomyces. The cellwalls contained LL-A 2 pm, meso- $\mathrm{A}_{2} \mathrm{pm}$, glycine and galactose (cell-wall chemotype $\mathrm{X}$ ), and whole-cells contained galactose. Therefore, these characteristics of strains AB-110 and AA-107 were considered to be those of the genus Kitasatosporia proposed by OMURA et al. ${ }^{17)}$. Although strains AB-110 and AA-107 resembled some of Micromonospora- and Nocardiopsis-strains in having both LL- and meso- 
$\mathrm{A}_{2} \mathrm{pm}$, the isolates were different from them chemotaxonomically or morphologically. Some strains in the genus of Micromonospor ${ }^{14,15,42)}$ contain LL- and meso- $\mathrm{A}_{2} \mathrm{pm}$ and glycine in the cell-walls, and contain arabinose and xylose in the whole-cells. Micromonospora strains form spores in singly, in pairs or short chains on substrate mycelia. A strain in the genus Nocardiopsis ${ }^{26,42,43)}$ contains LL- and meso- $\mathrm{A}_{2} \mathrm{pm}$ in the cell-walls, and contains galactose in the whole-cells. It forms fragmented substrate mycelia, spores of irregular lengths and some special structures such as sclerotia or sporangia in aerial mycelia.

Strains reported in the genus Kitasatosporia are $K$. seta $^{16,18,21)}, K$. griseola $^{21)}$ and K. phosalacine ${ }^{21)}$. Those have been validly published ${ }^{44,45)}$. But other strains ${ }^{23,25)}$ in the genus Kitasatosporia have not yet been validly published.

The three strains, $K$. setae IFO 14216, K. griseola IFO 14371 and $K$. phosalacinea IFO 14372, were characterized at the species level on the basis of differences in the $\mathrm{G}+\mathrm{C}$ content, mass color of aerial and substrate mycelia, color of the soluble pigment, tolerance to $\mathrm{NaCl}$, gelatin liquefaction, milk coagulation, nitrate reduction, utilization of carbon sources and antibiotics produced $\left.{ }^{17}{ }^{21}\right)$. K. setae IFO 14216 has a $\mathrm{G}+\mathrm{C}$ content of $73.1 \%$. White aerial mycelia and ivory substrate mycelia develop. A yellow maple color soluble pigment is produced. It is tolerant to less than $1.5 \% \mathrm{NaCl}$. Gelatin is not liquefied. Milk is peptonized and coagulated. Nitrate is not reduced. L-Arabinose, D-xylose and $\mathrm{D}$-glucose are utilized, but not $\mathrm{D}$-fructose, sucrose, $i$-inositol, L-rhamnose, raffinose, D-mannitol or cellulose. The antibiotic, setamycin, is produced. K. griseola IFO 14371 has a $\mathrm{G}+\mathrm{C}$ content of $66.0 \%$. Gray aerial mycelia and golden olive substrate mycelia develop. A pink soluble pigment is produced. It is tolerant to less than $2.0 \% \mathrm{NaCl}$. Gelatin is not liquefied. Milk is peptonized and coagulated. Nitrate is not reduced. L-Arabinose, D-xylose, D-glucose and raffinose are utilized, but not D-fructose, sucrose, $i$-inositol, L-rhamnose, D-mannitol or cellulose. The antibiotic, setamycin, is produced. $K$. phosalacinea IFO 14372 has a $\mathrm{G}+\mathrm{C}$ content of $66.6 \%$. White aerial mycelia and bamboo color substrate mycelia develop. A light tan soluble pigment is produced. It is tolerant to less than $2.0 \% \mathrm{NaCl}$. Gelatin is not liquefied. Milk is peptonized but not coagulated. Nitrate is reduced. L-Arabinose, D-xylose, D-glucose, D-fructose, sucrose, L-rhamnose and raffinose are utilized, but not $i$-inositol, D-mannitol or cellulose. A different antibiotic, phosalacine, is produced.

The results of taxonomic comparison of strains AB-110 and AA-107 with three species of Kitasatosporia are summarized in Table 3.

Strains AB-110 and AA-107 have very similar G+C contents to that of $K$. setae, but not to that of $K$. griseola or $K$. phosalacinea. Therefore, the isolates were considered to be related to $K$. setae.

However, strains AB-110 and AA-107, and $K$. setae were found to differ on taxonomic comparison. Strains AB-110 and AA-107 were different from $K$. setae in the ratio of LL- and meso- $\mathrm{A}_{2} \mathrm{pm}$ in the cellwalls, mass color of aerial and substrate mycelia, soluble pigment produced, tolerance to $\mathrm{NaCl}$, gelatin liquefaction, milk coagulation, utilization of carbon sources and antibiotics produced. According to our results, $K$. setae showed the same characteristics as those described by $\bar{O}_{M U R A}{ }^{18,17,21)}$, except for the ratio of LL- and meso- $\mathrm{A}_{2} \mathrm{pm}$ contents. The ratio of LL- and meso- $\mathrm{A}_{2} \mathrm{pm}$ contents in strains $\mathrm{AB}-110$ and AA-107, and $K$. setae were $3: 1,3: 1$ and $1: 3$, respectively, although that of $K$. setae was reported to be almost $1: 1^{18,17)}$. Strains AB-110 and AA-107 developed gray aerial mycelia and brown substrate mycelia. A soluble pigment was not produced. Strains AB-110 and AA-107 were tolerant to less than $3.5 \%$ and $4.5 \% \mathrm{NaCl}$, respectively: $K$. setae is tolerant to $1.5 \% \mathrm{NaCl}$. Gelatin was liquefied. 
Table 3. Comparison of Kitasatosporia papulosa AB-110 and Kitasatosporia grisea AA-107 with Kitasatosporia setae IFO 14216, Kitasatosporia griseola IFO 14371 and Kitasatosporia phosalacinea IFO 14372.

\begin{tabular}{|c|c|c|c|c|c|}
\hline & $\begin{array}{l}K . \text { papulosa } \\
\text { AB-110 }\end{array}$ & $\begin{array}{l}\text { K. grisea } \\
\text { AA-107 }\end{array}$ & $K . \operatorname{setae}^{17,21)}$ & K. griseola ${ }^{21), a}$ & $\begin{array}{l}K . \\
\text { phosalacinea }^{21), a}\end{array}$ \\
\hline Aerial mycelium & $\begin{array}{l}\text { Long } \\
\text { spore chain }\end{array}$ & $\begin{array}{l}\text { Long } \\
\text { spore chain }\end{array}$ & $\begin{array}{l}\text { Long } \\
\text { spore chain }\end{array}$ & $\begin{array}{l}\text { Long } \\
\text { spore chain }\end{array}$ & $\begin{array}{l}\text { Long } \\
\quad \text { spore chain }\end{array}$ \\
\hline $\begin{array}{l}\text { Fragmentation of } \\
\text { substrate mycelium }\end{array}$ & None & None & None & None $^{21\rangle}$ & None $^{212}$ \\
\hline $\begin{array}{l}\text { Zoospores and } \\
\text { sporangia }\end{array}$ & None & None & None & None & None \\
\hline Spore chain & $\geqq 20$ & $\geqq 20$ & $\geqq 20$ & $\geqq 20$ & $\geqq 20$ \\
\hline Spore shape & Cylindrical & Cylindrical & Cylindrical & Cylindrical & Cylindrical \\
\hline Spore surface & $\begin{array}{l}\text { Smooth with } \\
\text { some warts }\end{array}$ & Smooth & Smooth & Smooth & Smooth \\
\hline Aerial mycelium & Gray & Gray & White & Gray & White \\
\hline Substrate mycelium & Brown & Brown & Ivory & Golden olive & Bamboo \\
\hline Soluble pigment & None & None & Yellow maple & Pink & Light $\tan$ \\
\hline Temp for growth $\left({ }^{\circ} \mathrm{C}\right)$ & $14 \sim 36$ & $15 \sim 38$ & $15 \sim 37$ & $15 \sim 37$ & $15 \sim 42$ \\
\hline $\mathrm{pH}$ for growth & $5.0 \sim 9.5$ & $5.0 \sim 9.5$ & $5.5 \sim 9.0$ & $5.5 \sim 9.0$ & $5.5 \sim 9.0$ \\
\hline $\mathrm{NaCl}$ tolerance $(\%)$ & $3.5>$ & $4.5>$ & $1.5>$ & $2.0>$ & $2.0>$ \\
\hline Starch hydrolysis & + & + & + & + & + \\
\hline Gelatin liquefaction & + & + & - & - & - \\
\hline Milk peptonization & + & + & + & + & + \\
\hline Milk coagulation & - & - & + & + & - \\
\hline Nitrate reduction & - & - & - & - & + \\
\hline Melanin formation & - & - & - & - & - \\
\hline \multicolumn{6}{|l|}{$\begin{array}{l}\text { Utilization of } \\
\text { carbon sources: }\end{array}$} \\
\hline L-Arabinose & + & + & + & + & + \\
\hline D-Xylose & + & + & + & + & + \\
\hline D-Glucose & + & + & + & + & + \\
\hline D-Fructose & + & + & - & - & + \\
\hline Sucrose & + & - & - & - & + \\
\hline$i$-Inositol & + & - & - & - & - \\
\hline L-Rhamnose & + & + & - & - & + \\
\hline Raffinose & + & - & - & + & + \\
\hline D-Mannitol & + & + & - & - & - \\
\hline Cellulose & - & - & - & - & - \\
\hline Cell-wall & Type X & Type X & Type X & Type X & Type X \\
\hline $\begin{array}{l}\text { Ratio of } \mathrm{LL}-\text { and } \\
\text { meso- } \mathrm{A}_{2} \mathrm{pm} \text { in } \\
\text { cell-walls }\end{array}$ & $3: 1$ & $3: 1$ & $\begin{array}{l}1: 3 \\
\text { (reported to } \\
\text { be } 1: 1^{17)} \text { ) }\end{array}$ & $1: 1$ & $1: 1$ \\
\hline Phospholipid & Type II & Type II & Type $I^{21\rangle}$ & Type II & Type II \\
\hline \multirow[t]{2}{*}{ Quinone } & MK-9 $\left(\mathrm{H}_{8}\right)$ & $\operatorname{MK}-9\left(\mathrm{H}_{6}\right)$ & No data & No data & No data \\
\hline & MK-9 $\left(\mathrm{H}_{8}\right)$ & $\mathrm{MK}-9\left(\mathrm{H}_{8}\right)$ & & & \\
\hline GC content $(\%)$ & 72.0 & 72.0 & $73.1^{21)}$ & 66.0 & 66.6 \\
\hline $\begin{array}{l}\text { Antibiotic } \\
\text { produced }\end{array}$ & Carbapenems & Carbapenems & Setamycin ${ }^{17)}$ & Setamycin & Phosalacine \\
\hline
\end{tabular}

a All data from ref 21.

Milk was peptonized but not coagulated. In addition to L-arabinose, D-xylose and D-glucose utilized by $K$. setae, $\mathrm{D}$-fructose, sucrose, $i$-inositol, L-rhamnose, raffinose and $\mathrm{D}$-mannitol were utilized by strain AB-110, and D-fructose, L-rhamnose and D-mannitol by strain AA-107. Carbapenem antibiotics were produced. Furthermore, strain AB-110 was different from strain AA-107 in spore surface, tolerance to $\mathrm{NaCl}$ and utilization of carbon sources. Strain $\mathrm{AB}-110$ developed smooth spores with some warts. 
It was tolerant to less than $3.5 \% \mathrm{NaCl}$, not $4.5 \%$. In addition to carbon sources utillized by strain AA-107, sucrose, $i$-inositol and raffinose were utilized by strain AB-110.

Considering the separation of the three approved species in the genus Kitasatosporia ${ }^{17,20)}$, it is concluded that strains AB-110 and AA-107 are new species of Kitasatosporia, respectively. The proposed name for strain AB-110 is $K$. papulosa sp. nov., due to the warts on its spore surface, and that for strain AA-107 is $K$. grisea sp. nov., due to the gray color of its aerial mycelia.

\section{Description}

Descriptions of the two new species are given below.

Kitasatosporia papulosa sp. nov. (L. adj. papulosa, warty)

Morphology: Long aerial mycelia develop from substrate mycelia. The structure of aerial mycelia is of the Rectus-Flexibilis type. The mature spore chains comprise more than 20 spores each. The spores are cylindrical and $0.7 \sim 0.9 \times 1.0 \sim 1.2 \mu \mathrm{m}$ in size. The spore surface is smooth with some warts. The substrate mycelia in agar media are not fragmented. Zoospores and sporangia are not formed.

Color of Colonies: Aerial mycelia are gray on yeast extract - malt extract agar, oatmeal agar and inorganic salts - starch agar. Substrate mycelia are brown. A soluble pigment is not produced.

Growth Temperature: $14 \sim 36^{\circ} \mathrm{C}$.

Growth pH: $\mathrm{pH} 5.0 \sim 9.5$.

Tolerance to $\mathrm{NaCl}$ : Less than $3.5 \%$.

Physiological Characteristics: Starch is hydrolyzed. Gelatin is liquefied. Milk is peptonized but not coagulated. Nitrate is not reduced. Melanin is not formed. L-Arabinose, D-xylose, Dglucose, D-fructose, sucrose, $i$-inositol, L-rhamnose, raffinose and D-mannitol are utilized for growth, but not cellulose.

Antibiotic Susceptibility: Resistant to $\beta$-lactam antibiotics. Sensitive to streptomycin, tetracycline, erythromycin, fosfomycin and chloramphenicol.

Cell-wall Composition and Whole-cell-sugar Composition: $\mathrm{LL}_{\mathrm{L}} \mathrm{A}_{2} \mathrm{pm}$, meso- $\mathrm{A}_{2} \mathrm{pm}$, glycine and galactose are present in the cell-walls. Galactose is present in the whole-cells.

Phospholipid and Menaquinones: Phosphatidylethanolamine is present. The major menaquinones are $\mathrm{MK}-9\left(\mathrm{H}_{6}\right)$ and $\mathrm{MK}-9\left(\mathrm{H}_{3}\right)$.

$\mathrm{G}+\mathrm{C}$ Content: $72.0 \%$.

Antagonistic Product: The type strain produces carbapenem antibiotics.

Habitat: This organism may be distributed in soil. Only a single strain is known.

Type Strain: The type strain is strain AB-110, which was isolated from soil in Yokohama-city, Japan. A culture of this strain has been deposited at the Fermentation Research Institute, Agency of Industrial Science and Technology, Japan, with the accession number, FERM 9000, at the Institute of Applied Microbiology, University of Tokyo, Japan, with the accession number, IAM 13637, and at the Japan Collection of Microorganisms, RIKEN, Japan, with the accession number, JCM 7250.

Kitasatosporia grisea sp. nov. (M.L. adj. grisea, gray)

Morphology: Long aerial mycelia develop from substrate mycelia. The structure of aerial mycelia is of the Rectus-Flexibilis type. The mature spore chains comprise more than 20 spores each. The spores are cylindrical and $0.7 \sim 0.9 \times 1.0 \sim 1.2 \mu \mathrm{m}$ in size. The spore surface is smooth. The substrate mycelia in agar media are not fragmented. Zoospores and sporangia are not formed. 
Color of Colonies: Aerial mycelia are gray on yeast extract - malt extract agar, oatmeal agar and inorganic salts - starch agar. Substrate mycelia are brown. A soluble pigment is not produced.

Growth Temperature: $15 \sim 38^{\circ} \mathrm{C}$.

Growth pH: pH 5.0 9.0.

Tolerance to $\mathrm{NaCl}$ : Less than $4.5 \%$.

Physiological Characteristics: Starch is hydrolyzed. Gelatin is liquefied. Milk is peptonized but not coagulated. Nitrate is not reduced. Melanin is not formed. L-Arabinose, D-xylose, Dglucose, D-fructose, L-rhamnose and $\mathrm{D}$-mannitol are utilized for growth, but not sucrose, $i$-inositol, raffinose or cellulose.

Antibiotic Susceptibility: Resistant to $\beta$-lactam antibiotics. Sensitive to streptomycin, tetracycline, erythromycin, fosfomycin and chloramphenicol.

Cell-wall Composition and Whole-cell-sugar Composition: LL- and meso- $\mathrm{A}_{2} \mathrm{pm}$, glycine and galactose are present in the cell-walls. Galactose is present in the whole-cells.

Phospholipid and Menaquinones: Phosphatidylethanolamine is present. The major menaquinones are MK-9 $\left(\mathrm{H}_{8}\right)$ and MK-9 $\left(\mathrm{H}_{8}\right)$.

G+C Content: $72.0 \%$.

Antagonistic Product: The type strain produces carbapenem antibiotics.

Habitat: This organism may be distributed in soil. Only a single strain is known.

Type Strain: The type strain is strain AA-107, which was isolated from soil in Nikko-city, Japan. A culture of this strain has been deposited at the Institute of Applied Microbiology, University of Tokyo, Japan, with the accession number, IAM 13638, and at the Japan Collection of Microorganisms, RIKEN, Japan, with the accession number, JCM 7249.

\section{Acknowledgment}

The authors wish to thank Dr. K. Komagata of the Institute of Applied Microbiology, The University of Tokyo, for his kind advice and encouragement. They are also wish to thank Dr. A. HrRAIshi of the above mentioned institute for determination of the menaquinone system and the DNA base composition.

\section{References}

1) Kahan, J. S.; F. M. Kahan, R. Goggelman, S. A. Currie, M. Jackson, E. O. Stapley, T. W. Miller, A. K. Miller, D. Hendlin, S. Mochales, S. Hernandez, H. B. Woodruff \& J. Birnbaum: Thienamycin, a new $\beta$-lactam antibiotic. I. Discovery, taxonomy, isolation and physical properties. J. Antibiotics 32: $1 \sim 12,1979$

2) Box, S. J.; J. D. Hood \& S. R. SPEAR: Four further antibiotics related to olivanic acid produced by Streptomyces olivaceus: Fermentation, isolation, characterization and biosynthetic studies. J. Antibiotics 32: $1239 \sim 1247,1979$

3) Stapley, E. O.; P. J. Cassidy, J. Tunac, R. L. Monaghan, M. Jackson, S. Hernandez, S. B. Zimmerman, J. M. Mata, S. A. Currie, D. Daoust \& D. Hendeln: Epithienamycins-novel $\beta$-lactams related to thienamycin. I. Production and antibacterial activity. J. Antibiotics 34:628 636, 1981

4) Okamura, K.; S. Hirata, A. Koki, K. Hori, N. Shibamoto, Y. Okumura, M. Okabe, R. Okamoto, K. Kouno, Y. Fukagawa, Y. Shimauchi, T. Ishikura \& J. LeIn: PS-5, a new $\beta$-lactam antibiotic. I. Taxonomy of the producing organism, isolation and physico-chemical properties. J. Antibiotics 32: 262 271,1979

5) Imada, A.; Y. Nozaki, Y. Kintaka, K. Okonogi, K. Kitano \& S. Harada: C-19393 $\mathrm{S}_{2}$ and $\mathrm{H}_{2}$, new carbapenem antibiotics. I. Taxonomy of the producing strain, fermentation and antibacterial properties. J. Antibiotics 33: 1417 1424, 1980

6) Kawamura, Y.; Y. Yasuda, M. Mayama \& K. TANaKa: Asparenomycins A, B and C, new carbapenem antibiotics. I. Taxonomic studies on the producing microorganisms. J. Antibiotics 35: 10 14, 1982 
7) Nakayama, M.; A. Ifasaki, S. Kimura, T. Mizoguchi, S. Tanabe, A. Murakam, I. Watanabe, M. OKuChi, H. Itoh, Y. SAINo, F. Kobayashi \& T. Mori: Carpetimycins A and B, new $\beta$-lactam antibiotics. J. Antibiotics 33: 1388 1390, 1980

8) Tsuir, N.; K. Nagashima, M. Kobayashi, Y. Terui, K. Matsumoto \& E. Kondo: The structures of pluracidomycins, new carbapenem antibiotics. J. Antibiotics 35: 536 540, 1982

9) Miyadoh, S.; T. Shomura, T. Itō \& T. Ninda: Streptomyces sulfonofaciens sp. nov. Int. J. Syst. Bacteriol. 33: $321 \sim 324,1983$

10) Parker, W. L.; M. L. Rathnum, J. S. Wells, Jr., W. H. Trejo, P. A. Principe \& R. B. Sykes: SQ 27,860, a simple carbapenem produced by species of Serratia and Erwinia. J. Antibiotics 35: 653 660, 1982

11) Lechevalier, M.P. \& H. Lechevalier: Chemical composition as a criterion in the classification of aerobic actinomycetes. Int. J. Syst. Bacteriol. 20: 435 443, 1970

12) Gottlieb, D.: Order I. Actinomycetales Buchanan 1917, 162. In Bergey's Manual of Determinative Bacteriology. 8th Ed., Eds., R. E. Buchanan \& N. E. GibBons, pp. 657 659, Williams \& Wilkins Co., Baltimore, 1974

13) Nakamura, Y.; K. Ishil, E. ONo, M. Ishihara, T. Kohda, Y. Yokogawa \& H. Shibai: A novel naturally occurring carbapenem antibiotic, AB-110-D, produced by Kitasatosporia papulosa novo sp. J. Antibiotics 41: $707 \sim 711,1988$

14) KaWAmoto, I.; T. OKa \& T. NARA: Cell wall composition of Micromonospora olivoasterospora, Micromonospora sagamiensis, and related organisms. J. Bacteriol. 146: 527 534, 1981

15) Nelson, R. A.; J. A. Pope, Jr., G. M. Luedemann, L. E. McDaniel \& C. P. Schaffner: Crisamicin A, a new antibiotic from Micromonospora. I. Taxonomy of the producing strain, fermentation, isolation, physico-chemical characterization and antimicrobial properties, J. Antibiotics 39: 335 344, 1986

16) Ōmura, S.; Y. IwaI, Y. Takahashi, K. KoJima, K. Otoguro \& R. ÖIwa: Type of diaminopimelic acid different in aerial and vegetative mycelia of setamycin-producing actinomycete KM-6054. J. Antibiotics 34: $1633 \sim 1643,1981$

17) Ōmura, S.; Y. Takahashr, Y. IwaI \& H. Tanaka: Kitasatosporia, a new genus of the order Actinomycetales. J. Antibiotics 35:1013 1019, 1982

18) OMura, S.; Y. TAKahashi, Y. IwaI \& H. TANAKA: Revised nomenclature of Kitasatosporia setalba. Int. J. Syst. Bacteriol. 35: 221, 1985

19) TaKahash, Y.; Y. IwaI \& S. OMura: Relationship between cell morphology and the types of diaminopimelic acid in Kitasatosporia setae. J. Gen. Appl. Microbiol. 29: 459 465, 1983

20) TAKahashi, Y.; T. KuWANo, Y. IWAI \& S. OMURA: Some characteristics of aerial and submerged spores of Kitasatosporia setae. J. Gen. Appl. Microbiol. 30: 223 229, 1984

21) TAKahashi, Y.; Y. IwaI \& S. ŌMURA: Two new species of the genus Kitasatosporia, Kitasatosporia phosalacinea sp. nov. and Kitasatosporia griseola sp. nov. J. Gen. Appl. Microbiol. 30: 377 387, 1984

22) Tamamura, T.; T. Sawa, K. Isshiki, T. Masuda, Y. Homma, H. Innuma, H. Naganawa, M. Hamada, T. TAKEUCHI \& H. UMEZAWA: Isolation and characterization of terpentecin, a new antitumor antibiotic. J. Antibiotics 38: 1664 1669, 1985

23) Shimazu, A.; K. Furihata, H. Seto \& N. Ōtake: Dimorphism and phylogenic position of the genus Kitasatosporia. Actinomycetologica 50:2 13, 1987

24) InaOKa, Y.; H. TAmaoki, S. TAKahashi, R. Enokita \& T. OKazaki: Propioxatins A and B, new enkephalinase B inhibitors. I. Taxonomy, fermentation, isolation and biological properties. J. Antibiotics 39: $1368 \sim 1377,1986$

25) Iwami, M.; O. Nakayama, H. Terano, M. Kohsaka, H. Aoki \& H. Imanaka: A new immunomodulator, FR-900494: Taxonomy, fermentation, isolation and physico-chemical and biological characteristics. J. Antibiotics 40: 612 622, 1987

26) Takahashi, A.; Y. OKami \& K. Hotra: Consideration on the taxonomic position of Nocardiopsis mutabilis. Actinomycetologist 47: 8 14, 1985

27) Nonomura, H. \& Y. Ofara: Distribution of actinomycetes in soil. (VI) A culture method effective for both preferential isolation and enumeration of Microbispora and Streptosporangium strains in soil (part 1). J. Ferment. Technol. 47: 463 469, 1969

28) Nakamura, Y.; E. ONo, T. Kohda \& H. Shibai: Highly targeted screening system for carbapenem antibiotics. J. Antibiotics 42: 73 83, 1989

29) Hasegawa, T.; M. TAkizawa \& S. TANida: A rapid analysis for chemical grouping of aerobic actinomycetes. J. Gen. Appl. Microbiol. 29: 319 322, 1983

30) Shirling, E. B. \& D. Gottlieb: Methods for characterization of Streptomyces species. Int. J. Syst. Bacteriol. 16: 313 340, 1966 
31) Waksman, S. A. (Ed.): The Actinomycetes. Vol. 2. Classification, Identification and Description of Genera and Species. Williams \& Wilkins Co., Baltimore, 1961

32) Kornerup, A. \& J. H. Wanscher (Ed.): Methuen Handbook of Colour. 3rd Ed. Eyre Methuen Ltd., London, 1978

33) YamaGuCHI, T.: Comparison of the cell-wall composition of morphologically distinct actinomycetes. J. Bacteriol. 89: 444 453, 1965

34) BeCker, B.; M. P. Lechevalier \& H. A. LeChevalier: Chemical composition of cell-wall preparations from strains of various form-genera of aerobic actinomycetes. Appl. Microbiol. 13: 236 243, 1965

35) Lechevalier, M. P.; C. DE Bievre \& H. A. Lechevalier: Chemotaxonomy of aerobic actinomycetes. Phospholipid composition. Biochem. Syst. Ecol. 5: $249 \sim 260,1977$

36) Tamaoka, J.; Y. Katayama-Fujimura \& H. Kuraishi: Analysis of bacterial menaquinone mixtures by high performance liquid chromatography. J. Appl. Bacteriol. 54: $31 \sim 36,1983$

37) YamADA, K. \& K. Komagata: Taxonomic studies on coryneform bacteria III. DNA base composition of coryneform bacteria. J. Gen. Appl. Microbiol. 16:215 224, 1970

38) Saito, H. \& K. Miura: Preparation of transforming deoxyribonucleic acid by phenol treatment. Biochem. Biophys. Acta 72: 619 629, 1963

39) Tamaoka, J. \& K. Komagata: Determination of DNA base composition by reversed-phase high-performance liquid chromatography. FEMS Microbiol. Lett. 25: 125 128, 1984

40) Lechevalier, M.P.; A. E. Stern \& H. A. Lechevalier: Phospholipids in the taxonomy of actinomycetes. In Actinomycetes. Eds., K. P. ShaAL \& G. Pulverer, Zbl. Bakt, Suppl. 2. pp. 111 116, Gustav Fisher Verlag, Stuttgart, New York, 1981

41) Collins, M.D.; M. FAulKner \& R. M. Keddie: Menaquinone composition of sporeforming actinomycetes. System. Appl. Microbiol. 5: 20 29, 1984

42) SeIno, A. (Ed.): Housenkin no Dotei Jikkensho (Identification Methods for Actinomycetes) (in Japanese). Nippon Housenkin Kenkyukai, Tokyo, 1985

43) Shearer, M. C.; P. M. Colman \& C. H. Nash, III: Nocardiopsis mutabilis, a new species of nocardioform bacteria isolated from soil. Int. J. Syst. Bacteriol. 33: 369 374, 1983

44) Validation of the publication of new names and new combinations previously effectively published outside the IJSB. List No. 11. Int. J. Syst. Bacteriol. 33: 672 674, 1983

45) Validation of the publication of new names and new combinations previously effectively published outside the IJSB. List No. 19. Int. J. Syst. Bacteriol. 35: 535, 1985 